\title{
Pengembangan Bahan Ajar IPA Tema 8 menggunakan Model Project Based Learning di Sekolah Dasar
}

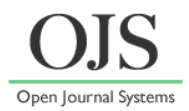

\author{
Suang Kupon Syukur, Yanti Fitria, Farida F. \\ Program Studi Pendidikan Dasar, Program Pascasarjana, FIP Universitas Negeri Padang, Indonesia \\ Email: Suangkuponsyukur10@gmail.com
}

DOI: https://doi.org/10.33369/pendipa.6.1.120-127

\begin{abstract}
This research was motivated by teaching materials that do not do project learning. This research aimed to describe the development process and produce thematic integrated teaching materials on theme 8 using a valid, practical, and effective Project Based Learning (PPA) model for fifth grade elementary school students. This type of research is research and development. The development model carried out is a 4-D model. This research was conducted at SDN 39 Mata Air. The research subjects were students of class $V$. The validity of the research data was obtained using the RPP validation questionnaire sheet and teaching materials. Practicality data were collected through the lesson plan implementation observation sheet, teacher and student questionnaire responses. The effectiveness is taken from the activities, and student learning outcomes. Based on the validity test, data was obtained that the lesson plans and teaching materials from expert validators and category validators were very valid. The practicality test results from the implementation of lesson plans, teacher responsibility costs and student assessment are very practical categories. The results of the effectiveness test on the results of activities with the active category and learning outcomes obtained a proportion of the results from the minimum completeness criteria. Based on these results, it can show that integrated thematic teaching materials using the Project Based Learning (PPA) model for grade $V$ primary school students are valid, practical, and effective.
\end{abstract}

Keywords: PJBL, Integrated Thematic Learning, Teaching Materials.

\begin{abstract}
ABSTRAK
Riset ini dilatarbelakangi oleh bahan ajar yang kurang melakukan pembelajaran kegiatan proyek. Peniltian ini bertujuan untuk mendeskripsikan proses pengembangan serta menghasilkan bahan ajar tematik terpadu tema 8 dengan memakai model Project Based Learning (PJBL) untuk siswa kelas V SD yang valid, praktis, dan efektif. Penelitian pengembangan (research and development) merupakan jenis dari riset. Model pengembangan yang dilakukan adalah model 4-D. Penelitian ini dilakukan di SDN 39 Mata Air. Subjek penelitian yaitu siswa kelas V. Data penelitian tes validitas diperoleh dengan memakai lembar angket validasi RPP serta bahan ajar. Data kepraktisan dikumpul dengan lembar pengamatan keterlaksanaan RPP, angket tanggapan pendidik serta siswa. Keefektifan diambil dari aktivitas, serta hasil belajar siswa. Berdasarkan uju validitas, didapatkan data bahwa RPP dan bahan ajar dari validator ahli dan validator praktisi dengan kategori sungguh valid. Keputusan tes praktikalitas dari keterlaksanaan RPP, penilaian respon guru dan penilaiaan reson siswa dengan kategori sangat praktis. Hasil uji efektifitas terhadap penilaian aktivitas siswa dengan kategori aktif dan penilaian hasil belajar memperoleh persentase ketuntasan hasil dari KKM. Berdasarkan hasil tersebut dapat disimpulkan bahan ajar tematik terpadu memakai model Project Based Learning (PJBL) untuk siswa kelas V SD sudah valid, praktis, dan efektif.
\end{abstract}

Kata Kunci : PJBL, Integrated Thematic Learning, Teaching Materials. 


\section{PENDAHULUAN}

Pendidikan merupakan suatu proses dalam menghasilkan generasi penerus bangsa yang berkualitas baik dari segi sikap, keterampilan, dan pengetahuan. Untuk meningkatkan kualitas pendidikan harus memiliki strategi yang dilakukan agar pendidikan dapat di tingkatkan dengan baik, misalnya dengan meningkatkan anggaran pendidikan, perbaikan fasilitas, dan penigkatan mutu guru, tetapi pelaksanaannya masih terdapat berbagai kendala yang menjadi perhatian. Menurut Prananda, (2020) Kurikulum sebaiknya disesuaikan dengan perkembangan zaman, agar kurikulum yang dipakai sesuai dengan pembelajaran abad 21. Pembelajaran abad 21 dilakukan untuk memperbarui kualitas pembelajaran yang menekankan berbasis masalah agar dapat meningkatkan keterlibatan siswa dalam merancang kegiatan pembelajaran yang signifikan dengan dunia fakta serta mengelaborasi pembelajaran student-centered (Zubaidah 2016). Pembelajaran abad 21 disebut masa pengetahuan (knowledge age), dimana pembelajaran diartikan sebagai prosedur belajar yang di bangun oleh pendidik untuk menumbuhkan inspirasi berpikir yang bisa menumbuhkan pengetahuan peserta didik saat mengkonsruksi wawasan aktual sebagai usaha demi menumbuhkan kemampuan yang bagus kepada teori belajar (Fahmi 2013).

Arti pendidikan abad 21 sekarang sungguh signifikan pada tujuan pendidikan di Indonesia sebagaimana terkandung dalam Undang Undang Sisdiknas No. 20 Pasal 3 Tahun 2003) Pendidikan Nasional berperan untuk menumbuhkan pengetahuan serta membangun karakter dan kebudayaan suku yang terhormat dalam bentuk mencerdaskan aktivitas warga negara, bermaksud demi meningkatnya kemampuan siswa supaya menjadi orang yang berakhlak serta beragama terhadap Tuhan Y.M.E, sehat, bijaksana, pandai, inovatif, mandiri, serta menjadi bangsa yang absolut dan konsisten. Karakteristik pembelajaran abad 21 yang menuntut sekolah untuk melakukan strategi belajar mengajar yang berfokus pada siswa supaya mempunyai akhlak, konsisten, serta afeksi, dengan mengimplementasikan serta mengarahkan tingkah laku yang bagus salah satunya dengan adanya kurikulum 2013 (Komara 2018). Kurikulum 2013 bertujuan membentuk siswa yang mempunyai karakter yang mencerminkan sikap spritual, sikap sosial, dan mempunyai wawasan serta mempunyai pengetahuan berfikir serta berbuat inovatif, bermanfaat, responsif, mandiri, kolaboratif yang terintegrasi (Permendikbud, Pasal 1 ayat 1, No. 20 Tahun 2016).

Terlaksanannya pembelajaran berdasarkan kurikulum 2013 yang diawali dari perancangan, penerapan, serta evaluasi. Pembelajaran yang dilakukan sesuai aspek pendukung adalah alat belajar mengajar yang dipakai dalam tahap belajar mengajar. Salah satu alat belajar mengajar yaitu bahan ajar yang dipakai dalam tahap pembelajaran, akan menghasilkan pembelajaran yang baik dan berkualitas bagi guru dan siswa untuk melakukan aktivitas belajar di ruangan serta berguna sebagai data penilaian buat pendidik guna memahami ketercapaian standar pengetahuan yang sudah dikasih (Adi,2016). Bahan ajar merupakan perangkat pembelajaran yang sungguh berarti untuk diperhatikan penerapan dalam belajar mengajar. Bahan ajar di Sekolah Dasar (SD) yaitu dasar awal untuk menentukan keberhasilan siswa pada tahap berikutnya dari pendidikan. Bahan ajar berperan penting sebagai sumber untuk melaksanakan pendidikan yang memberikan pedoman sehingga dapat dikuasai siswa pada proses pembelajaran seperti pada proses pembelajaran Ilmu Pengetahuan Alam (IPA) (Liliawati 2019). Proses pembelajaran IPA pendidik mesti dapat mewujudkan kegiatan pembelajaran yang cocok pada pengembangan pengetahuan, sikap, dan keterampilan. Guru perlu memperhatikan pembelajaran yang berfokus kepada interaksi siswa dan obyek pembelajaran, agar siswa dapat mengamati langsung secara nyata. Melalui jalan mencari tahu mengenai alam secara terstruktur, sehingga tidak cuma kompetensi gabungan kemampuan yang berbentuk hasil namun juga salah satu proses invensi (Fitria 2017).

Kemampuan dalam meningkatkan pembelajaran IPA akan tercapai dengan menggunakan bahan ajar yang cocok dengan pendidik. Bahan ajar adalah suatu hal yang berguna diperhatikan dalam pencapaian kemampuan yang di inginkan. Hal ini dilakukan karena bahan ajar akan mendukung fluensi sistem pembelajaran yang dibagikan pendidik di sekolah. Seorang guru yang profesional tentu mengukur ketercapaian proses pembelajarannya dengan melakukan evaluasi setiap pembelajaran yang dilakukan. Guru menilai dirinya sendiri sejauh mana bahan ajar yang sudah dipersiapkan bisa diaplikasikan di sekolah. Hal demikian terlihat ketika periset melaksanakan pengamatan serta tanya jawab terhadap wali kelas SD kelas 
V pada tanggal 5 sampai 6 September 2019. Perangkat pembelajaran yang dipakai masih belum cocok terhadap karakteristik siswa, sehingga yang diinginkan dalam tahap belajar mengajar belum terlaksana dengan efisien. Perangkat pembelajaran yang dimaksud adalah perangkat pembelajaran IPA berbentuk Rencana Pelaksanaan Pembelajaran(RPP) serta bahan ajar.

RPP yang digunakan masih terdapat berbagai aspek dan kegiatan yang kurang sesuai dengan tujuan pembelajaran. Rumusan indikator pembelajaran belum memenuhi kriteria indikator yang benar. Tujuan pembelajaran yang dirumuskan belum mengandung tujuan yang sesuai dengan penurunan indikator. Aktivitas belajar yang dilakukan amat biasa sehingga belum tersusun bagus sesuai pada jenjang proses pembelajaran. prosedur dan teknik pembelajaran belum menggambarkan konsep menemukan. Bahan ajar IPA yang dipakai dalam pembelajaran masih kurang cocok pada tujuan pembelajaran IPA. Sehingga kegiatan proses pembelajaran kurang tercapai secara efektif. Bahan ajar kurang memberi ruang bagi siswa untuk mengamati konsep yang dipelajari terlebih dahulu, tetapi langsung memberikan penjelasan dalam bentuk materi. Siswa dalam proses pembelajaran dituntut menghafal materi, tanpa mengetahui bagaimana menerapkan konsep yang dipelajari.

Akibatnya siswa mudah melupakan konsep yang telah dipelajari sehingga pembelajaran menjadi kurang bermakna. Permasalahan bahan ajar yang dipakai dalam proses belajar mengajar sedikit mengadopsi pemahaman peserta didik secara menyeluruh, teks bacaan yang masih terikat, dan gambar yang digunakan masih belum cukup menarik. Langkah-langkah pembelajaran pada buku guru terlihat bahwa sudah di muat menggambarkan langkah kegiatan yang di terapkan dalam kurikulum 2013 tapi masih kurang tepat dalam pemahaman siswa

Bahan ajar perlu ditingkatkan guna memudahkan pendidik dalam memberikan teori saat belajar sehingga pendidik tidak kekurangan sumber materi yang digunakan sebagai panduan, selain itu media pendukung bahan ajar yang mudah di akses dan mudah dipelajari sehingga media dapat dijadikan siswa untuk belajar mandiri (Priatna et al. 2017). Rancangan bahan ajar harus sinkron dengan tuntutan kurikulum 2013 dengan melaksanakan kegiatan pembelajaran yang beriontasi kepada kegiatan proyek yang akan membantu peningkatan Learning Skills peserta didik Pengembangan bahan ajar butuh cara pembelajaran yang akan mendukung supaya arah pembelajaran dapat dipahami oleh peserta didik (Fajri 2018). Selain RRP dan bahan ajar faktor yang dapat menyebabkan kurang aktifnya peserta didik dalam proses pembelajaran yaitu penggunaan model pembelajaran. Untuk menciptakan suasana yang kondusif dan menyenangkan perlu adanya penggunaan model pembelajaran yang atraktif. Salah satunya menggunakan model pembelajaran Projec Based Learning (PjBL). Merupakan model yang disarankan kurikulum 2013. Peneliti mengembangkan bahan ajar IPA dengan menggunakan model $\mathrm{PjBL}$ pada kurikulum tingkat satuan.

Model PjBL adalah salah satu model pembelajaran yang mengikutsertakan peserta didik dalam menganalisis kompetensi serta kemampuan dengan proses yang sistematis, pengetahuan fakta serta akurat yang dibuat untuk menciptakan produk (Risda Amini 2015). Bertujuan memungkinkan peserta didik untuk memperoleh pengetahuan melalui realisasi proyek yang diciptakan dengan bekerja sama untuk menyelesaikan permasalahan yang bisa menghasilkan perangkat kompleks, menciptakan jasa, serta barang (Hartini 2017). Menghasilkan sebuah produk suatu keterampilan yang butuh ditingkatkan siswa untuk memecahkan masalah serta menemukan konsep baru dalam proses pembelajaran, sehingga proses pembelajaran terpusat dengan siswa dapat dilaksanakan dengan baik (Ardianti, Pratiwi, and Kanzunnudin 2017).

Berdasarkan hasil observasi dan karakteristik materi pembelajaran IPA Pada Tema 8 kelas $\mathrm{V}$ dengan menggunakan PjBL yang berpusat pada peserta didik, pembelajaran kolaboratif dan melibatkan siswa dalam menyelesaikan proyek agar mampu mengintegrasikan masalah nyata dengan lingkungan, sehingga siswa memiliki pengalaman belajar yang fakta cocok dengan kejadian serta keperluan di lapangan.

\section{METODE PENELITIAN}

Penelitian pengembangan atau Research and Development (R\&D) adalah semacam riset yang bisa diaksanakan dalam mengerjakan sebentuk barang. Pengembangan yaitu salah satu desain riset yang dipakai demi menciptakan barang spesifik serta mencoba keberhasilan barang yang sudah dikembangkan (Sugiyono,2012). Riset pengembangan adalah teknik riset yang terstruktur demi mencari temuan, mendeskripsikan, membenarkan, memajukan, 
menciptakan, mengecek keberhasilan barang yang terbaik, baru, efisien, praktis, bernilai, serta bermanfaat(Putra,2012).

Tujuan riset adalah hal yang sungguh penting untuk dilakukan karena tidak dapat terus menerus bergantung pada intuisi serta pengalaman saja untuk membenarkan serta meningkatkan pendidikan (Arifin, Bumi, and Way 2020). Model 4D (four-D models) adalah model yang dipakai dalam riset ini. Menurut Thiangarajan (dalam Faisal, 2014:97-100) bahwa, "Pengembangan model four-D ada 4 langkah yaitu: (1) define (pendifinisian), (2) design (perancangan), (3) develop (pengembangan), dan (4) disseminate (penyebaran)"sebab model tersebut tidak memerlukan tahapan yang berlebihan serta sekalian sesuai dalam pengembangan materi pembelajaran melalui model PjBL. Tujuan dari riset ini untuk mengembangkan perangkat pembelajaran melalui model $\mathrm{PjBL}$ melalui dukungan teknologi berbentuk softwareScratch (Iskandar dan Raditya, 2017).

Pengembangan pembelajaran dilaksanakan melalui tahap 4D. Hasil evalusai dari bahan ajar yang dikembangkan mendapatkan hasil yang sungguh produktif. Sehingga bahan ajar yang dikembangkan patut dipakai sebagai suatu sumber pembelajaran dalam aktivitas belajar.

\section{HASIL DAN PEMBAHASAN}

Pengembangan menggunakan model pengembangan $4 \mathrm{D}$, definisi akibat riset dibagi menjadi beberapa tahap yaitu: tahap pendefinisian, perancangan, pengembangan, serta tahap penyebaran. Berikut definisi dari hasil riset yaitu sebagai berikut:

\section{Analisis Kurikulum}

Analisis yang dilakukan bertujuan untuk mengetahui cakupan materi, tujuan pembelajaran, dan pemilihan model pembelajaran yang dijadikan sebagai acuan untuk mengembangkan bahan ajar. Tahap analisis kurikulum dilaksanakan melalui menelaah KD untuk merumuskan indikator. Dari indikator dirumuskan tujuan pembelajaran yang hendak dicapai oleh peserta didik. Selanjutnya perumusan indikator digunakan untuk pengembangan bahan ajar tematik terpadu pada tema 8 (Lingkungan Sahabat Kita) di kelas V semester II yang sesuai dengan standar isi pada pembelajaran tematik terpadu pada tingkat SD Kurikulum 2013.

\section{Hasil Analisis Kebutuhan}

Analisis kebutuhan yang dilaksanakan setelah selesai menganilisis kurikulum untuk memahamii kejadian dasar yang diperlukan dalam pengembangan bahan ajar yang peneliti lakukan sesuai dengan kurikulum 2013. Penerapan kurikulum 2013 menggunakan buku guru dan buku peserta didik menjadi patokan bagi guru dalam pelaksanaan proes pembelajaran. oleh karena itu peneliti melakukan analisis terhadap buku guru dan peserta didik.

Kegiatan analisis lebih difokuskan pada aktivitas pembelajaran yang didapatkkan dalam buku pendidik serta siswa tema 8 (Lingkungan Sahabat Kita) kelas V SD. Berdasarkan analisis aktivitas pebelajaran yang terdapat daalam buku tema 8 yang peneliti lakukan saat studi pendahuluan, peneliti menemukan bahwa aktivitas pembelajaran belum mampu menjawab secara keseluruhan pelaksanaan pembelajaran.

Tabel 1. Analisis Aktivitas pada Buku Guru dan Peserta didik Tema 8

\begin{tabular}{|l|l|}
\hline $\begin{array}{l}\text { Aktivitas Pada buku } \\
\text { Didik pada Kegiatan } \\
\text { Pyoek }\end{array}$ & $\begin{array}{l}\text { Hasil Analisis } \\
\text { Pada }\end{array}$ \\
\hline & $\begin{array}{l}\text { Kegiatan berbasis proyek } \\
\text { pada buku sudah terlihat } \\
\text { prinsip pembelajaran tematik } \\
\text { karena terdapat beberapa } \\
\text { muatan dalam pelaksanaan } \\
\text { pembelajaran proyek, namun } \\
\text { kegiatan langkah proyek } \\
\text { yang dilakukan masih belum } \\
\text { tepat. Karena kegiatan } \\
\text { proyek perlu membuat } \\
\text { rancanga dan langkah- } \\
\text { langkah kegiatan. Hal yang } \\
\text { seharusnya dilakukan seperti } \\
\text { peserta didik menyusun } \\
\text { perencanaan, menyususn } \\
\text { jadwal pelaksanaan proyek } \\
\text { dan kegiatan monitoring } \\
\text { yang dilakukan guru. Jika di } \\
\text { amati belum terlihat proyek } \\
\text { apa yang dihasilkan. }\end{array}$ \\
\hline
\end{tabular}




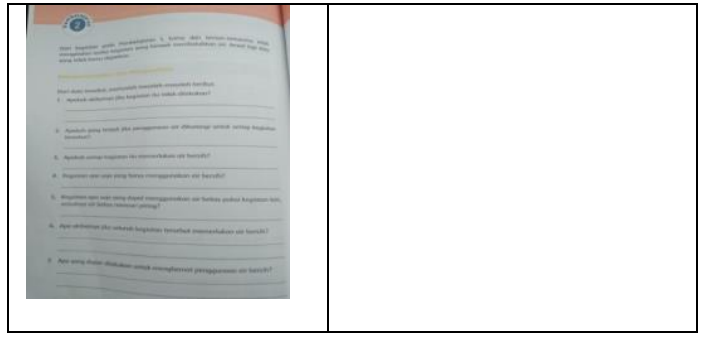

Deskripsi di atas memberi pengaruh terhadap keterampilan siswa dalam menyelesaikan masalah, menumbuhkan dan mempraktikkan kompetensi mengendalikan sumber yang menjadi tujuan kompetensi inti dalam aspek keterampilan dalam kurikulum 2013 dalam permendikbud No. 21 tahun 2016 tentang standar isi yang seharusnya dimiliki oleh peserta didik di SD.

\section{Analisis Karakteristik Peserta Didik}

Analisis tingkah laku siswa bertujuan untuk menelaah sikap siswa khususnya kelas V SD. Analisis yang dilakukan meliputi perkembangan intelektual dan bahasa serta gaya belajar. Analisis digunakan dengan mengambil angket respon guru dan siswa, bertujuan untuk memperoleh informasi tentang motivasi, keterampilan dan gaya belajar siswa dalam mengikuti proses pembelajaran tematik. Dalam perkembangan intelektual, keterampilan serta bahasa siswa kelas $\mathrm{V}$ berdasarkan angket yang ditemukan bahwa perkembanganya nya sudah meningkat. Hal oni di dapat dari persentase perkembangan intelektual peserta didik $83,33 \%$ yang menunjukkan peserta didik dapat membaca, menulis, menghitung dengan jelas, dapat mengelompokkan, mengasosiasikan angka dan memiliki kemampuan memecahkan masalah yang sederhana dari materi yang diberikan dalalm proses pembelajaran.

Kegiatan analisis membantu dalam pengembangan bahan ajar tematik terpadu menggunakan model $\mathrm{PjBL}$ yang digunakan dalam proses pembelajaran. berdasarkan keragaman karakter peserta didik yang diperoleh, maka dilaksanakan riset yang menampilkan sarana belajar berupa bahan ajar yang lain dari yang dipakai lebih dahulu, seperti gambar yang berwarna, warna yang menarik, bahan ajar yang memuat langkah-langkah kegiatan peserta didik belajar sambil membuat suatu karya serta memfasilitasi peserta didik dalam bekerja sama dan berkomunikasi.

\section{Penyusunan Bahan Ajar}

Penyusunan terhadap bahan ajar tematik terpadu cocok dengan KI dan KD pembelajaran yang dipastikan kurikulum. KD pada kurikulum dijabarkan dengan menentukan indikator pembelajaran. Indikator hasil penjabaran KD digunakan dalam merancang bahan ajar cocok dengan menggunakan PjBL. Teori ajar yang dirancang dengan menerapkan siswa pada kegiatan pelaksanaan proyek dalam didkusi kelompok sehingga mendorong peserta didik untuk aktif dalam berinteraksi dalam kelompok belajar. Bahan ajar bisa melancarkan siswa dalam membuat proyek karena bahan ajar memuat langkah-langkah yang jelas pada setiap kegiatan yang dilakukan peserta didik selama menggunakan model PjBL.

Bahan ajar dirancang menggunakan bahasa yang gampang dimengerti oleh siswa, materi dicocokan dengan lingkungan siswa sesuai dengan dengan tema 8 Lingkungan Sahabat Kita. Bahan ajar dilengkapi dengan gambar, warna dan ukuran buku yang atraktif buat siswa. Perancangan bahan ajar ini bisa dipahami peserta didik sehingga bisa membantu keterlaksanaan proses dan tujuan pembelajaran.

Perancangan bahan ajar dikonversi dari struktur bahan ajar menurut Depdiknas yang terdapat atas: (1) Cover, (2) Kata Pengantar. (3) Petunjuk Penggunaan, (4) Standar Kompetensi Lulusan dan Kegiatan Inti, (5) Kompetensi Dasar, (6) Materi Pembelajaran, (7) Daftar Isi, (8) Kompetensi Dasar dan Indikator, (9) Langkah-langkah PjBL dalam Bahan Ajar, (10) Rangkuman, (11) Evaluasi, (12) Daftar Pustaka.

\section{Hasil Langkah Pengembangan (Develop)}

Langkah pengembangan dilakukan sesudah tahap perencanaan. Kegiatan pada tahap ini meliputi validasi bahan ajar dan RPP selanjutnya dilakukan tes produk untuk mengetahui efisien serta daya guna bahan ajar yang dikembangkan. Tes validitas dilakukan melalui memvalidasi bahan ajar oleh validator, setelah itu dilaksanakan perbaikan. Pengujian praktikalitas dengan cara mencobakan bahan ajar yang telah dikembangkan dalam proses pembelajaran di kelas V SD. Sebelum dilakukan validasi bahan ajar terlebih dahulu dilakukan penilaian terhadap intrumen validasi untuk mendapatkan instrumen pengumpulan data yang valid.

Instrumen pengumpul data berupa lembar instrumen validasi RPP, lembar instrumen validasi bahan ajar, lembar instrumen keterlaksanaan RPP, Lembar instrumen tanggapan pendidik maupun siswa terhadap praktikalitas bahan ajar. Lembar instrumen aktivitas peserta didik dan lembar instrumen 
keterampilan peserta didik. Lembar intstrumen tersebut divalidasi oleh 5 Orang Ahli.

Hasil evaluasi dari validator terhadap isi instrumen pengumpul data dapat dilihat sebagai berikut.

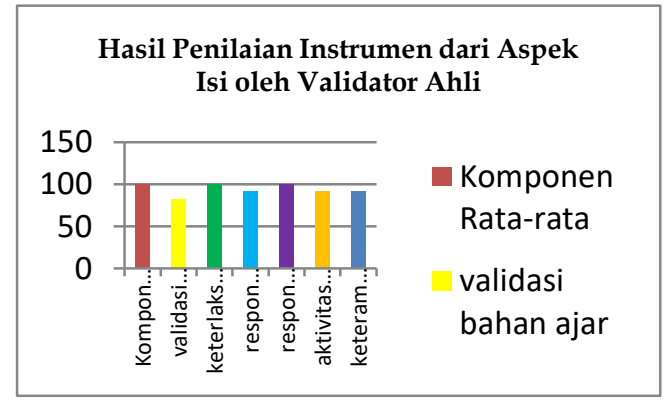

\section{Gambar 1. Diagram Batang Hasil Penilaian Instrumen dari Aspek isi}

Instrumen pengumpul data dari aspek isi sudah dinyatakan sangat valid dengan rata-rata 94,28\% karena isntrumen validasi RPP, instrumen validasi bahan ajar, instrumen keterlaksanaan RPP, instrumen tanggapan pendidik, instrumen peserta didik, dan instrumen aktivitas peserta didik, serta instrumen keterampilan peserta didik sudah mencantumkan petunjuk instrumen yang jelas dan sesuai antara instrumen dengan kisi-kisi yang dirancang serta pernyataan tepat untuk memvalidasi.

Hasil penilaian dari validator terhadap bahasa pada instrumen pengumpulan data bisa dilihat dalam tabel 2 berikut:

Tabel 2. Hasil Penilaian Instrumen dari Aspek Bahasa oleh Validator Ahli

\begin{tabular}{|c|c|c|c|}
\hline No & Komponen & $\begin{array}{l}\text { Rata- } \\
\text { rata }\end{array}$ & Kategori \\
\hline 1 & $\begin{array}{l}\text { Instrumen validasi } \\
\text { RPP }\end{array}$ & 100 & $\begin{array}{l}\text { Sangat } \\
\text { Valid }\end{array}$ \\
\hline 2 & $\begin{array}{ll}\text { Intrumen } & \text { validasi } \\
\text { bahan ajar } & \\
\end{array}$ & 75 & $\begin{array}{l}\text { Sangat } \\
\text { Valid }\end{array}$ \\
\hline 3 & $\begin{array}{l}\text { Instrumen } \\
\text { keterlaksaanaan RPP }\end{array}$ & 87,5 & $\begin{array}{l}\text { Sangat } \\
\text { Valid }\end{array}$ \\
\hline 4 & $\begin{array}{ll}\begin{array}{l}\text { Instrumen } \\
\text { guru }\end{array} & \text { respon } \\
\end{array}$ & 87,5 & $\begin{array}{l}\text { Sangat } \\
\text { Valid }\end{array}$ \\
\hline 5 & $\begin{array}{ll}\text { Instrumen } & \text { respon } \\
\text { peserta didik } & \end{array}$ & 100 & $\begin{array}{l}\text { Sangat } \\
\text { Valid }\end{array}$ \\
\hline 6 & $\begin{array}{l}\text { Instrumen aktivitas } \\
\text { peserta didik }\end{array}$ & 87,5 & $\begin{array}{l}\text { Sangat } \\
\text { Valid }\end{array}$ \\
\hline 7 & $\begin{array}{l}\text { Instrumen } \\
\text { keterampilan peserta } \\
\text { didik }\end{array}$ & 100 & $\begin{array}{l}\text { Sangat } \\
\text { Valid }\end{array}$ \\
\hline & Rata-rata akhir (\%) & 91,07 & $\begin{array}{l}\text { Sangat } \\
\text { Valid }\end{array}$ \\
\hline
\end{tabular}

Instrumen pengumpul informasi Aspek bahasa dijelaskan sangat valid dengan rata-rata
91,07\%. karena huruf dalam instrumen validasi RPP, instrumen respon guru, instrumen respon siswa, instrumen aktivitas siswa, dan instrumen keterampilan siswa sudah memakai bahasa yang sesuai dengan kaidah Ejaan Bahasa Indonesia (EBI) yang gampang diketahui dan dimengerti.

Validasi instrumen pangumpul data instrumen yang dikumpulkan bisa dilihat dalam tabel 3 berikut ini:

Tabel 3. Rekapitulasi Penilaian Instrumen Oleh Validator Ahli

\begin{tabular}{|c|c|c|c|c|c|c|}
\hline \multirow{2}{*}{ No } & \multirow{2}{*}{ Komponen } & \multicolumn{3}{|c|}{ Aspek } & \multirow{2}{*}{$\begin{array}{l}\text { Rata- } \\
\text { rata }\end{array}$} & \multirow{2}{*}{$\begin{array}{l}\text { Katego } \\
\text { ri }\end{array}$} \\
\hline & & Isi & Bahasa & Grafik & & \\
\hline 1 & Intrumen validasi RPP & 100 & 100 & 100 & 100 & $\begin{array}{l}\text { Sangat } \\
\text { Valid }\end{array}$ \\
\hline 2 & $\begin{array}{l}\text { Instrumen validasi bahan } \\
\text { ajar }\end{array}$ & 83 & 75 & 93,75 & 83,91 & Valid \\
\hline 3 & $\begin{array}{l}\text { Instrumen } \\
\text { keterlaksanaan RPP }\end{array}$ & 100 & 87,5 & 93,75 & 93,75 & $\begin{array}{l}\text { Sangat } \\
\text { Valid }\end{array}$ \\
\hline 4 & Instrumen Respon Guru & 92 & 87,5 & 93,75 & 91 & $\begin{array}{l}\text { Sangat } \\
\text { Valid }\end{array}$ \\
\hline 5 & Instrumen Peserta Didik & 100 & 100 & 93,75 & 89 & Valid \\
\hline 6 & $\begin{array}{l}\text { Instrumen } \\
\text { Peserta Didik }\end{array}$ & 92 & 87,5 & 87,5 & 89 & Valid \\
\hline \multirow[t]{2}{*}{7} & $\begin{array}{l}\text { Instrumen keterampilan } \\
\text { peserta didik }\end{array}$ & 92 & 100 & 100 & 97,33 & $\begin{array}{l}\text { Sangat } \\
\text { Valid }\end{array}$ \\
\hline & \multicolumn{4}{|c|}{ Rata-rata Akhir (\%) } & $93,62 \%$ & $\begin{array}{l}\text { Sangat } \\
\text { Valid }\end{array}$ \\
\hline
\end{tabular}

Rekapitulasi ini menyampaikan bahwa aspek isi, bahasa dan grafikan dinyatakan sangat valid dengan rata-rata93,62\% bisa disimpulkan instrumen pengumpulan bukti riset telah mampu dipakai validasi RPP, validasi abahn ajar, keterlaksanaan RPP, dan keterampilan peserta didik. Dari berbagai instrumen yang di validasi oleh validator ahli bahwa periset melaksanakan perbaikan sesuai arah serta petunjuk yang di peroleh bisa dilihat dalam tabel berikut.

Hasil belajar merupakan tolak ukur efektivitas bahan ajar dengan melihat hasil belajar siswa yang dilaksanakan. Hasil belajar dinilai dari aspek sikap, kompetensi serta kemampuan siswa. Penilaian dinilai selama proses pembelajaran berlangsung dengan menggunakan lembar instrumen pengamatan sikap dan kemampuan peserta didik yang disediakan.

Evaluasi bagian karakter dilaksanakan sewaktu proses pembelajaran dilaksanakan memakai notasi jurnal. Notasi jurnal berupa kertas lembar pengamatan. Pengamatan dilakukan secara terus menerus dengan memakai lembar pengamatan yang sudah dipersiapkan. Pengamatan dilaksanakan oleh peneliti saat setiap pembelajaran yang terdapat dalam tiga kali pembelajaran. Lembar pengamatan diisi berasaskan keputusan pengamatan perilaku pada saat pembelajaran. Penilaian perilaku siswa memakai lembar pengamatan serta 
mendeskripsikan capaian perilaku psikis serta kemasyarakatan siswa.

Berdasarkan hasil diagnosis notasi jurnal selama proses pembelajaran tema 8 (Lingkungan Sahabat Kita) yang dilakukan. Maka penilaian sikap peserta didik dapat dilihat pada tabel 4.

Tabel 4. Hasil Belajar Aspek Sikap di Kelas V SDN 39 Mata Air

\begin{tabular}{c|c|c|c|c|c}
\hline \multicolumn{2}{c|}{ Spritual } & \multicolumn{4}{|c|}{ Sosial } \\
\hline $\begin{array}{c}\text { Berperilaku } \\
\text { Bersyukur }\end{array}$ & Berdoa & Disiplin & Peduli & $\begin{array}{l}\text { Tanggung } \\
\text { Jawab }\end{array}$ & $\begin{array}{l}\text { Percaya } \\
\text { Diri }\end{array}$ \\
\hline 3.08 & 2,83 & 3.02 & 3,05 & 3,05 & 2,83 \\
\hline 2,95 & & & & 2,98 & \\
\hline \multicolumn{2}{c|}{ Baik } & & & Baik & \\
\hline
\end{tabular}

Analisis aspek sikap yang sudah dicapai, pembelajaran dengan memakai bahan ajar tematik terpadu dengan memakai model PjBL pada tema (Lingkungan Sahabat Kita) dapat membantu dalam meningkatkan sikap spiritual seperti terlihat peserta suka memberi ,selalu menerima penugasan dengan sikap terbuka, dan terlihat berdoa sebelum dan sesudah belajar. Sementara sikap sosial peserta didik sudah baik, hal demikian terlihat peserta didik memiliki sikap disiplin seperti mengikuti peraturan yang ada di kelas, tertib dalam melaksanakan tugas, dan mengumpulkan tugas/pekerjaan tepat waktu. Sikap peduli terlihat peserta didik ingin menolong teman yang kesusahan saat belajar serta meminjamkan alat terhadap teman yang tidak membawa/memiliki.

Evaluasi perspektif kompetensi dilaksanakan sewaktu proses pembelajaran berlangsung dengan menganalisis soal-soal latihan yang diperoleh dalam setiap bahan ajar yang dikembangkan. Soal uji yang dipakai adalah bagian evaluasi dari bahan ajar yang dikembangkan. Soal diteskan di kelas V SDN 39 Mata Air. Dalam mendiagnosis hasil belajar siswa dipakai kriteria ketuntasan belajar. Ketuntasan belajar peserta didik diperoleh dari perbandingan hasil belajar siswa dengan KKM yang ditetapkan di sekolah.

Berdasarkan analisis hasil belajar yang diperoleh, tampak bahwa pembelajaran dengan memakai bahan ajar tematik terpadu tema 8 (Lingkungan Sahabat Kita) dengan menggunakan model PjBL dapat membantu peserta didik dalam mengetahui teori sehingga mendapatkan hasil yang bagus. Hal ini tampak dari rata-rata yang diperoleh peserta didik yaitu $91,66 \%$ berada diatas KKM sekolah yaitu 80 , dapat penilti simpulkan pembelajaran dengan memakai bahan ajar tematik terpadu menggunakan model PjBL di sudah efektif.

Evaluasi perspekttif kemampuan dilaksanakan sewaktu proses pembelajaran dilaksanakan dengan memakai rublik evaluasi. Evaluasi perspektif kemampuan lebih dipusatkan terhadap kemampuan peserta didik dalam menyusun aktivitas proyek yang tepat dengan teori dari pembelajaran PjBL. Data hasil evaluasi aspek keterampilan peserta didik bisa dilihat pada tabel 5 .

Tabel 5. Hasil Belajar Aspek Keterampilan di Kelas V SDN 39 Mata Air

\begin{tabular}{|c|c|}
\hline Pembelajaran & Rata-rata (\%) \\
\hline $\mathbf{1}$ & 91,66 \\
\hline $\mathbf{2}$ & 88,88 \\
\hline $\mathbf{3}$ & 94,44 \\
\hline Skor rata-rata akhir (\%) & $\mathbf{9 1 , 6 6}$ \\
\hline Kategori & Baik \\
\hline
\end{tabular}

Berdasarkan keputusan diagnosis pada hasil belajar siswa terhadap perspektif kemampuan yang sudah dilakukan, kemudian tampak bahwa pembelajaran dengan memakai bahan ajar tematik tema 8 (Lingkungan Sahabat Kita) dengan memakai model PjBL bisa mendukung menaikkan kemampuan siswa dengan rata-rata 91,66\% dengan kategori baik.

\section{KESIMPULAN}

Hasil riset menunjukkan bahwa bahan ajar tematik 8 (Lingkungan Sahabat Kita) dengan menggunakan model $\mathrm{PjBL}$ yang dihasilkan dalam riset pengembangan ini sungguh valid dari segi isi, segi kebahasaan dan segi kegrafikan dengan tingkatan rata-rata sangat valid. Hal ini dilihat berdasarkan hasil validasi ahli serta praktisi pendidikan sudah dilakukan, baik pada RPP serta pada bahan ajar yang dikembangkan sudah valid untuk dipakai dalam pembelajaran Tematik di Kelas V. Hasil penelitian menunjukan bahwa bahan ajar tematik tema 8 (Lingkungan Sahabat Kita) dengan memakai model PjBL secara keutuhan dalam golongan sangat praktis. Hal ini tampak dari hasil observasi keterlaksanaan RPP kepada pendidik yang mengajar, tanggapan pendidik, serta respon siswa. Hasil ini membagikan gambaran bahwa penggunaan RPP, bahan ajar oleh pendidik sungguh praktis, serta mendukung dalam melakukan proses pembelajaran tematik di kelas V SD. Hasil penelitian menunjukan bahwa bahan ajar tematik tema 8 (Lingkungan Sahabat Kita) 
dengan menggunakan $\mathrm{PjBL}$, telah dinyatakan efektif untuk meningkatkan efektifitas learning skill peserta didik dan hasil belajar. Aktivitas learning skill siswa dan hasil pengamatan siswa pada saat di tes dengan kategori aktif pada saat penyebaran dengan kategori sangat aktif. Penilaian hasil belajar dari aspek sikap pada dengan kategori sudah baik. Hasil belajar siswa dari aspek pengetahuan dengan rata-rata ketuntasan meningkat. Selanjutnya hasil belajar peserta didik dari ranah keterampilan dengan kategori sangat baik.

Berdasarkan hasil penilaian terhadap aktivitas learning skills siswa serta evaluasi hasil belajar untuk ketiga perspektif membagikan cerita yang sungguh bagus, dapat periset simpulkan pemakaian bahan ajar tematik terpadu tema 8 (Lingkungan Sahabat Kita) dengan memakai model PjBL dalam pembelajaran sudah efektif dilaksanakan.

\section{DAFTAR PUSTAKA}

Ardianti, Sekar Dwi, Ika Ari Pratiwi, and Mohammad Kanzunnudin. 2017. "Implementasi Project Based Learning (Pjbl) Berpendekatan Science Edutainment Terhadap Kreativitas Peserta Didik." Refleksi Edukatika: Jurnal Ilmiah Kependidikan 7(2): 145-50.

Arifin, Zaenal, Stit Al-hikmah Bumi, and Agung Way. 2020. "Metodologi Penelitian Pendidikan Education Research Methodology." STIT Al-Hikmah Bumi Agung Way Kanan 1: 3.

Fahmi, Aida Nur. 2013. "Kata Kunci: Pembelajaran Abad 21. Tematik Integratif. Sekolah Dasar.”

Fajri, Zaenol. 2018. "Bahan Ajar Tematik Dalam Pelaksanaan Kurikulum 2013.” Pedagogik 05(01): 100-108.

Fitria, Yanti. 2017. "Efektivitas Capaian Kompetensi Belajar Siswa Dalam Pembelajaran Sains Di Sekolah Dasar." Jurnal Inovasi Pendidikan Dan Pembelajaran Sekolah Dasar 1(2).

Hartini, Ayu. 2017. "Pengembangan Perangkat Pembelajaran Model Project Based Learning Untuk Meningkatkan Kemampuan Berpikir Kritis Siswa Sekolah Dasar." Jurnal
Pendidikan Dasar. 1: 6-16.

Komara, Endang. 2018. "Penguatan Pendidikan Karakter Dan Pembelajaran Abad 21." SIPATAHOENAN: South-East Asian Journal for Youth, Sports \& Health Education 4(1): 17-26.

Liliawati, Winny dkk. 2019. "Desain Bahan Ajar Fisika Dalam Jaringan (Daring) Berorientasi Pendidikan Karakter Untuk Siswa SMA.” Jurnal Inovasi dan Pembelajaran Fisika 6(2): 113-21.

Prananda, Gingga. 2020. "Pengembngan Media Video Pembelajaran Tema 6 Subtema 2 Untuk Siswa Kelas SD Negeri 17 Pasar Masurai 1." Jurnal Dharma PGSD 1(1): 3845.

Priatna, I Komang, I Made Putrama, Dewa Gede, and Hendra Divayana. 2017. "Pembelajaran Project Based Learning Pada Mata Pelajaran Videografi Untuk Siswa Kelas X Desain Komunikasi Visual Di SMK Negeri 1 Sukasada." 6: 70-78.

Risda Amini. 2015. "Pengaruh Penggunaan Project Learning Dan Motivasi Belajar Terhadap Hasil Belajar Siswa Kelas v SD.” Prosiding Seminar Nasional Pendidikan Biologi 2015, yang diselenggarakan oleh Prodi Pendidikan Biologi FKIP Universitas Muhammadiyah Malang, tema: "Peran Biologi dan Pendidikan Biologi dalam Menyiapkan Generasi Unggul dan Berdaya Saing Global" 4(2007): 339-45.

Sarah, Ratu, Fauziah Iskandar, and Aji Raditya. 2017. "Pengembangan Bahan Ajar ProjectBased Learning Berbantuan Scratch." (2013): 167-72.

Zubaidah, Siti. 2016. "Siti Zubaidah-STKIP Sintang-10Des2016." Seminar Nasional Pendidikan (2): 1-17. 